\begin{tabular}{|l|l|l}
\hline Received : March 2020 & Accepted: April 2020 & Published : April 2020
\end{tabular}

\title{
Efektivitas Briket Janjang Sawit dan Sekam Padi Desa Kandolo sebagai Sumber Energi Alternatif
}

\author{
Arief Muliawan $^{1 *}$, Ujiburahman ${ }^{2}$, Irianto $^{3}$ \\ ${ }^{1,2,3}$ Teknik Mesin, Sekolah Tinggi Teknologi Industri Bontang, Jl. Brigjen Katamso No.40 Bontang \\ *ariefstitek@gmail.com
}

\begin{abstract}
A research has been conducted on the characteristics of the results of the burning of briquettes in a mixture of oil palm and rice husk. This study aims to determine the effect of the composition of the resulting briquette mixing. The research method was carried out by testing dry shrinkage, shrinkage of fuel, levels of evaporating substances and water absorbency in briquettes. The characteristics of briquettes based on the size of the briquettes are Depreciation in the lowest dry shrinkage at $70 \%$ husk size by $0.81 \%$ and the highest at $90 \%$ husk size by $2.87 \%$. The lowest shrinkage of fuel shrinkage is at the husk size of $50 \%$ by $1.77 \%$ and the highest is at the size of the husk of $70 \%$ by $4.12 \%$. The lowest evaporation rate of briquettes at $60 \%$ and $80 \%$ of husk size is $1.52 \%$ and the highest is at $70 \%$ husk size of $8.57 \%$. The lowest water absorption rate at $80 \%$ husk size is $1.54 \%$ and the highest at $60 \%$ husk size

is

$8,20 \%$.
\end{abstract}

Keywords: briquettes, palm oil, rice husk, composition variation

\begin{abstract}
Abstrak
Telah dilakukan penelitian tentang karakteristik hasil pembakaran briket campuran janjang sawit dan sekam padi. Penelitian ini bertujuan untuk mengetahui pengaruh komposisi pencampuran hasil briket yang dihasilkan. Metode penelitian dilakukan dengan pengujian susut kering, susut bakar, kadar zat menguap dan kadar serap air pada briket. Karakteristik briket berdasarkan ukuran briket yakni Penyusutan pada susut kering terendah pada ukuran sekam $70 \%$ sebesar $0,81 \%$ dan tertinggi pada ukuran sekam $90 \%$ sebesar 2,87\%. Penyusutan susut bakar terendah pada ukuran sekam $50 \%$ sebesar $1,77 \%$ dan tertinggi pada ukuran sekam $70 \%$ sebesar $4,12 \%$. Kadar zat menguap briket terendah pada ukuran sekam $60 \%$ dan $80 \%$ sebesar $1,52 \%$ dan tertinggi pada ukuran sekam $70 \%$ sebesar $8,57 \%$. Kadar serap air terendah pada ukuran sekam $80 \%$ sebesar $1,54 \%$ dan tertinggi pada ukuran sekam $60 \%$
\end{abstract} sebesar $8,20 \%$.

Kata kunci : briket, janjang sawit, sekam padi, variasi komposisi

\section{Pendahuluan}

Energi alternatif dapat dihasilkan dari teknologi tepat guna yang sederhana dan sesuai untuk daerah pedesaan seperti briket dengan memanfaatkan limbah biomassa seperti tempurung kelapa, sekam padi, dan serbuk gergaji kayu. Sejalan dengan itu, berbagai pertimbangan untuk memanfaatkan tempurung kelapa, serbuk gergaji kayu jati, dan sekam padi menjadi penting mengingat limbah ini belum dimanfaatkan secara maksimal [1].
Briket dengan kualitas yang baik diantaranya memiliki sifat seperti tekstur yang halus, tidak mudah pecah, keras, aman bagi manusia dan lingkungan serta memiliki sifatsifat penyalaan yang baik. Sifat penyalaan ini diantaranya adalah mudah menyala, waktu menyala cukup lama, tidak menimbulkan jelaga, asap sedikit dan cepat hilang serta nilai kalor yang cukup tinggi. Lama tidaknya menyala akan mempengaruhi kualitas dan efisiensi pembakaran, semakin lama menyala 
dengan nyala api konstan akan semakin baik [2].

Beberapa jenis limbah seperti limbah pertanian seperti tongkol jagung [3], sekam padi [4], cangkang kelapa sawit [5], daun bintaro [6] dan sebagainya dapat dimanfaatkan sebagai energi alternatif pengganti BBM dan gas. Menurut Pari [7], untuk mengolah limbah tersebut menjadi lebih bermanfaat maka diperlukan tenologi alternatif.

Teknologi tersebut diantaranya pembuatan biobriket. Pencampuran ini akan diolah lebih lanjut menjadi produk yang lebih mempunyai nilai ekonomi seperti arang aktif, briket arang, serat karbon, dan arang kompos. Pada penelitian sebelumnya peneliti menggunakan janjang sawit [8], hasil menunjukan janjang sawit berpotensi sebagai biobriket. Pada penelitian yang lain percampuran antara dua atau lebih bahan menjadi biobriket. Penelitian dengan sekam padi dan biji salak [9] serta antara tabingga dan tongkol jagung [10] menunjukan kolaborasi bahan sangat menjanjikan untuk dibuat briket.

Janjang sawit disamping sebagai limbah dengan potensi yang cukup banyak juga memiliki nilai kalor yang cukup tinggi (>5000 kalori/gram), sehingga berpotensi untuk dijadikan campuran arang, selanjutnya diolah menjadi briket arang dengan ukuran partikel sehingga dapat dimanfaatkan sebagai bahan bakar alternatif [5]. Karakteristik pembakaran janjang sawit perlu dilakukan penelitian lebih mendalam sehingga limbah yang begitu besar ini dapat termanfaatkan. Janjang sawit juga memiliki kandungan senyawa kalium yang sangat baik untuk pupuk alami

Desa kandolo Kutai Timur merupakan salah satu daerah di Kalimantan Timur penghasil padi dan sawit. Dengan luas lahan pertanian yang cukup besar di daerah ini memungkinkan perolehan limbah dari kedua komoditi ini sangat besar sehingga dapat dimanfaatkan sebagai energi alternatif. Berdasarkan pemikiran diatas, peneliti melakukan studi efektivitas briket janjang sawit dan sekam padi desa Kandolo sebagai energi alternatif.

\section{Metoda Penelitian}

\subsection{Bahan dan Alat Penelitian}

Bahan yang dipergunakan pada penelitian ini diantaranya janjang sawit dan sekam padi yang diperoleh dari perkebunan dan persawahan Desa Kandolo Kutai Timur. Tepung kanji dipergunakan sebagai perekat dan air bersih sebagai pengencer.

Alat yang dipergunakan pada penelitian ini ialah gelas ukur, ember, kompor pembakaran, saringan 70 mesh, alat pencetak briket mengunakan pipa $1 \frac{1}{2}$ ', thermogan dan timbangan.

\subsection{Pembuatan Briket}

1. Pengarangan dilakukan pada kaleng biskuit selama 20 menit.

2. Arang sawit ditumbuk dan disaring dengan penyaring 70 mesh.

3. Perekat tepung kanji sebanyak 5\% dari bahan baku briket dicampurkan dengan air dengan perbandingan 1:20. Kanji sangat baik sebagai perekat briket.[4]. Campuran kanji dan kanji kemudian diaduk sampai tercampur sambil dipanaskan diatas kompor sampai larutan tepung kanji mengental dan berubah warna.

4. Larutan kanji dicampur dengan bahan baku briket yang telah dihitung perbandingan nya yakni 1:20. Pencampuran perekat dengan bahan baku secara merata dan pencetakan bahan dengan ukuran diameter $1 \frac{1}{2}$ '.

5. Bahan yang sudah tercampur kemudian dicetak dengan mengunakan alat press briket dengan tekanan kempa sebesar 10 $\mathrm{kg} / \mathrm{cm}^{2}$ selama 15 menit.

\subsection{Pengujian Briket Janjang sawit}

1. Pengujian kerapatan dinyatakan dengan perbandingan berat dan volume dari briket yang ada. Dihitung menggunakan Pers. (1).

$$
\rho=\frac{m}{V}
$$

dimana $\rho$ adalah massa jenis bahan $\left(\mathrm{gr} / \mathrm{cm}^{3}\right), m$ adalah massa benda (gr), dan $V$ adalah volume benda $\left(\mathrm{cm}^{3}\right)$. 
2. Pengujian kadar air menggunakan standar ASTM D7582-12. Kadar air atau susut kering dengan memperhitungkan hasil pengeringan dengan suhu $60 \mathrm{C}$ [11]. Dihitung menggunakan Pers. (2).

$$
M_{k}=\frac{V_{b}-V_{k}}{V_{b}} \times 100 \%
$$

dimana $M_{k}$ adalah susut kering (\%), $V_{b}$ adalah volume basah $\left(\mathrm{cm}^{3}\right)$, dan $V_{k}$ adalah volume kering $\left(\mathrm{cm}^{3}\right)$.

3. Susut bakar dengan memperhitungkan hasil pembakaran briket pada suhu $100{ }^{\circ} \mathrm{C}$ selama 5 menit [11], yang dapat dihitung menggunakan Pers. (3).

$$
S_{b}=\frac{V_{k}-V_{s d}}{V_{k}} \times 100 \%
$$

dimana $S_{b}$ adalah susut bakar (\%), $V_{k}$ adalah volume kering $\left(\mathrm{cm}^{3}\right)$, dan $V_{s d}$ adalah volume setelah dibakar $\left(\mathrm{cm}^{3}\right)$

4. Pengujian kadar zat yang menguap menggunakan ASTM D7582-12. Kadar zat menguap (volatile matter) briket dihitung berdasarkan Pers. (4) [11].

$$
V=\frac{B-C}{W} \times 100 \%
$$

dimana $V$ adalah kadar zat mudah menguap (\%), $B$ adalah berat contoh setelah dikeringkan (gr), $C$ adalah berat spesimen setelah dipanaskan pada tes zat menguap (gr), dan $W$ adalah berat contoh mula-mula pada kadar air (gr).

5. Daya serap air menunjukan seberapa besar briket menyerap air [11], [12]. Dapat dihitung menggunakan Pers. (5).

$$
D S A=\frac{B_{s}-B_{k}}{B_{k}} \times 100 \%
$$

dimana $D S A$ adalah daya serap air $(\%), B b$ adalah berat basah (gr), dan $B k$ adalah berat kering (gr).

\section{Hasil Penelitian}

Dalam penelitian ini digunakan alat pencetak briket dengan memenfaatkan pipa paralon yang tidak dimanfaatkan. Pencetak briket digunakan dengan ukuran $1 \frac{1 / 2}{2}$. Variasi sekam padi dengan perbandingan $100 \%, 90 \%$, $80 \%, 70 \%$, $60 \%$ dan $50 \%$ terhadap janjang sawit yang dimanfaatkan dalam penelitian ini dan dapat diukur diamater, tinggi dan massa briket hasil cetakan (Tabel 1, Tabel 2, dan Tabel 3).

\begin{tabular}{cccc}
\multicolumn{4}{c}{ Tabel 1. Ukuran briket sebelum dijemur } \\
\hline $\begin{array}{c}\text { Sekam } \\
\text { padi }\end{array}$ & $\begin{array}{c}\text { Diameter } \\
(\mathrm{cm})\end{array}$ & Tinggi $(\mathrm{cm})$ & Berat $(\mathrm{gr})$ \\
\hline $100 \%$ & 4,54 & 5,51 & 56 \\
$90 \%$ & 4,52 & 5,33 & 56 \\
$80 \%$ & 4,54 & 5,34 & 66 \\
$70 \%$ & 4,53 & 5,43 & 70 \\
$60 \%$ & 4,53 & 5,34 & 66 \\
$50 \%$ & 4,51 & 5,33 & 60 \\
\hline
\end{tabular}

Tabel 2. Ukuran briket sesudah dijemur

\begin{tabular}{cccc}
\hline $\begin{array}{c}\text { Sekam } \\
\text { padi }\end{array}$ & $\begin{array}{c}\text { Diameter } \\
(\mathrm{cm})\end{array}$ & Tinggi $(\mathrm{cm})$ & Berat (gr) \\
\hline $100 \%$ & 4,53 & 5,49 & 55 \\
$90 \%$ & 4,48 & 5,27 & 54 \\
$80 \%$ & 4,50 & 5,30 & 65 \\
$70 \%$ & 4,52 & 5,41 & 66 \\
$60 \%$ & 4,49 & 5,30 & 61 \\
$50 \%$ & 4,48 & 5,27 & 58 \\
\hline
\end{tabular}

Tabel 3. Ukuran briket sesudah dibakar

\begin{tabular}{cccc}
\hline $\begin{array}{c}\text { Sekam } \\
\text { padi }\end{array}$ & $\begin{array}{c}\text { Diameter } \\
(\mathrm{cm})\end{array}$ & Tinggi $(\mathrm{cm})$ & Berat $(\mathrm{gr})$ \\
\hline $100 \%$ & 4,45 & 5,47 & 53 \\
$90 \%$ & 4,45 & 4,53 & 52 \\
$80 \%$ & 4,44 & 5,29 & 64 \\
$70 \%$ & 4,43 & 5,40 & 60 \\
$60 \%$ & 4,45 & 5,29 & 60 \\
$50 \%$ & 4,47 & 5,20 & 54 \\
\hline
\end{tabular}

Hasil pencetakan briket pada ukuran 1/2" ditunjukan pada Gambar 1. Pada pencetakan dilakukan pada tekanan $10 \mathrm{~kg} / \mathrm{cm} 2$ selama 15 menit tiap briket. Perubahan fisik briket janjang sawit selama proses pengujian telah dilakukan oleh peneliti. Pengujian dilakukan pada saat sebelum dijemur, sesudah dijemur dan setelah di oven. Pengujian dilakukan 
untuk menunjukan perubahan fisik yang terjadi pada briket dengan ukuran briket $1 / 2$ ".

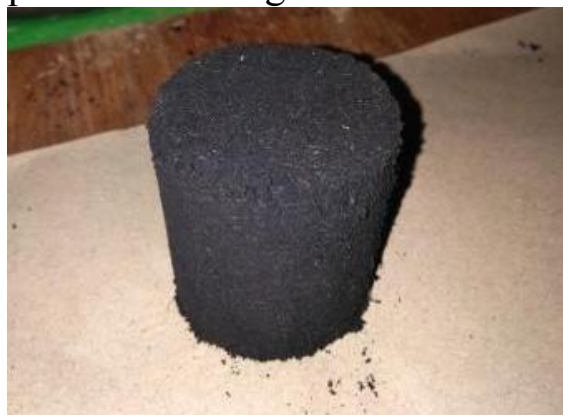

Gambar 1 Briket siap dianalisis

Perubahan susut briket ditunjukan pada Tabel 4. Perubahan ini terjadi pada keadaan ukuran kering, ukuran pada zat bakarnya, ukuran serap air dan ukuran kadar zat.

Tabel 4. Perhitungan susut briket

\begin{tabular}{ccccc}
\hline \multirow{2}{*}{ Ukuran } & \multicolumn{4}{c}{ Susut briket (\%) } \\
\cline { 2 - 5 } & $\begin{array}{c}\text { Zat } \\
\text { kering }\end{array}$ & $\begin{array}{c}\text { Zat } \\
\text { bakar }\end{array}$ & $\begin{array}{c}\text { Serap } \\
\text { air }\end{array}$ & $\begin{array}{c}\text { Kadar } \\
\text { zat }\end{array}$ \\
\hline $100 \%$ & 0,98 & 3,85 & 1,82 & 3,57 \\
$90 \%$ & 2,87 & 3,96 & 3,70 & 3,57 \\
$80 \%$ & 2,49 & 2,83 & 1,54 & 1,52 \\
$70 \%$ & 0,81 & 4,12 & 6,06 & 8,57 \\
$60 \%$ & 2,49 & 1,96 & 8,20 & 1,52 \\
$50 \%$ & 2,44 & 1,77 & 3,45 & 6,67 \\
\hline
\end{tabular}

Penyusutan pada susut kering disebabkan hilangnya kandungan air setelah proses pengeringan. Pengeringan ini dilakukan dengan mengangin-anginkan briket tanpa mengenai matahari langsung. Penyusutan pada susut kering terendah pada ukuran sekam 70\% sebesar $0,81 \%$ dan tertinggi pada ukuran sekam $90 \%$ sebesar 2,87\%. Susut kering ini sangat bergantung dari kualitas keringnya material tersebut.

Penyusutan pada saat pembakaran merupakan proses terakhir yang menentukan pada pembuatan briket. Bila briket rusak atau pecah dalam proses pembakaran maka briket tidak dapat diperbaiki lagi dan pembakaran akan tidak baik. Penyusutan susut bakar terendah pada ukuran sekam 50\% sebesar $1,77 \%$ dan tertinggi pada ukuran sekam $70 \%$ sebesar 4,12\%. Pembakaran yang mencapai titik leleh briket menyebabkan hilangnya kandungan air dri briket.

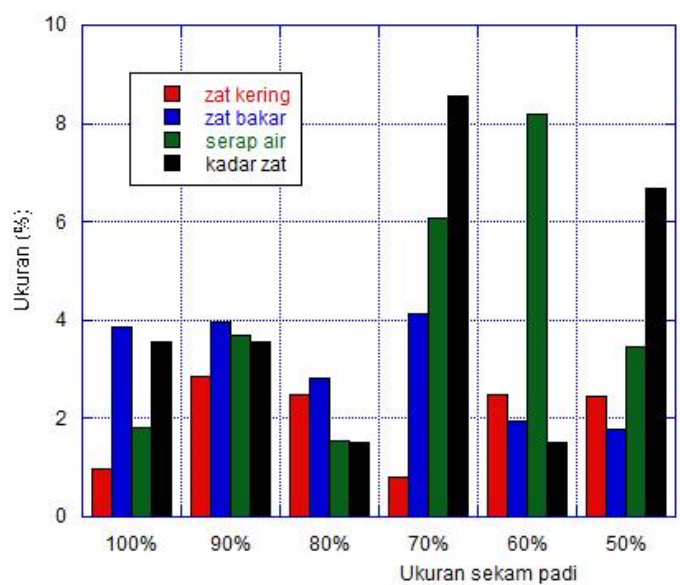

Gambar 2. Perubahan susut briket

Perubahan susut zat menguap terjadi akibat perubahan massa briket pada saat dipanaskan kemudian dibandingkan dengan pada saat memiliki kadar air. Kadar zat menguap briket terendah pada ukuran sekam $60 \%$ dan $80 \%$ sebesar $1,52 \%$ dan tertinggi pada ukuran sekam $70 \%$ sebesar $8,57 \%$.

Perubahan daya serap air pada briket janjang sawit terjadi pada penelitian ini. Daya serap air menunjukan seberapa besar briket tersebut dapat memegang air. Hal ini sangat dipengaruhi tekstur briket. Pada briket kasar memiliki daya serap yang rendah, hal ini disebabkan karena pada briket kasar didominasi oleh pori makro sehingga kemampuan mengikat air sangat rendah. Sebaliknya pada briket berstekstur halus, memiliki daya serap air yang tinggi, disebabkan oleh briket yang bertekstur halus didominasi oleh pori mikro sehingga kemampuan mengikat air sangat tinggi. Kadar serap air terendah pada ukuran sekam 80\% sebesar $1,54 \%$ dan tertinggi pada ukuran sekam $60 \%$ sebesar $8,20 \%$.

\section{Kesimpulan}

Karakteristik briket berdasarkan ukuran briket yakni penyusutan pada susut kering terendah pada ukuran sekam $70 \%$ sebesar $0,81 \%$ dan tertinggi pada ukuran sekam $90 \%$ sebesar $2,87 \%$. Penyusutan susut bakar terendah pada ukuran sekam $50 \%$ sebesar $1,77 \%$ dan tertinggi pada ukuran sekam $70 \%$ sebesar $4,12 \%$. Kadar zat menguap briket terendah pada ukuran sekam $60 \%$ dan $80 \%$ sebesar $1,52 \%$ 
dan tertinggi pada ukuran sekam $70 \%$ sebesar $8,57 \%$. Kadar serap air terendah pada ukuran sekam $80 \%$ sebesar $1,54 \%$ dan tertinggi pada ukuran sekam $60 \%$ sebesar $8,20 \%$.

\section{Daftar Pustaka}

[1] S. Amin, "Penelitian berbagai jenis kayu limbah pengolahan untuk pemilihan Bahan Baku briket Arang," Jurnal Sains dan Teknologi Indonesia 2, pp. 41-46.

[2] A. Hartoyo and H. Roliadi, Percobaan Pembuatan Briket Arang dari Lima Jenis Кауи. Bogor, 1978.

[3] U. B. Surono, "Peningkatan Kualitas Pembakaran Biomassa Limbah Tongkol Jagung Sebagai Bahan Bakar Alternatif dengan Proses Karbonisasi dan Pembriketan," Jurnal Rekayasa Proses, vol. 4, no. 1, pp. 13-18, 2010.

[4] D. Patabang, "Karakteristik Termal Briket Arang Sekam Padi Dengan Variasi Bahan Perekat," Jurnal Mekanikal, vol. 3, no. 2, pp. 286-292, 2012.

[5] Y. A. Mustafa, "Pengaruh Ukuran Partikel Cangkang Kelapa Sawit terhadap Efisiensi Kalor pada Briket Cangkang Kelapa Sawit," Prosiding Seminar Biologi, vol. 11, no. 1, 2014.

[6] A. W. Kasrun, W. Anggono, and T. Sutrisno, "Karakteristik Pembakaran Briket Dari Limbah Daun Pohon Bintaro," Jurnal Teknik Mesin, vol. 16, no. 2, pp. 64-70, 2016.

[7] G. Pari, Industri Pengolahan Кауи Teknologi Alternatif Pemanfaatan Limbah (makalah filsafah sains). Bogor: Institut Pertanian Bogor, 2002.

[8] A. Muliawan and Subhan, "Karakteristik Hasil Pembakaran Briket Janjang Sawit dengan Variasi Ukuran," PROSIDING SNITT POLTEKBA, vol. 3, no. 1, pp. 360363, 2018.

[9] F. Amalinda and M. Jufri, "Formulasi Briket Biorang Sekam Padi dan Biji Salak sebagai Sumber Energi Alternatif," JST (Jurnal Sains Terapan), vol. 4, no. 2, pp. 99-103, 2018.

[10] F. Amalinda, A. Muliawan, and N. Rismawati, "The effectiveness of tabingga briquettes and corncob briquettes as biocoal," Journal of Physics: Conference
Series, vol. 1434, no. 1, 2020.

[11] D. Darwis, Pengaruh Penambahan Zat Adiktif Tulang Terhadap Sifat-sifat Fisis Keramik. Palu: Universitas Tadulako, 2006.

[12] L. Mahmudin, "Analisis Struktur Mikroskopik dan Sifat-sifat Makroskopik Bahan Lempung Asal Daerah Pantai Barat Kabupaten Donggala," Jurnal Daerah Sulawesi Tengah, 2004. 